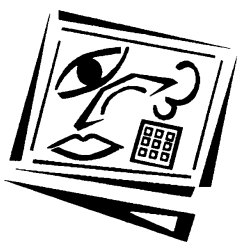

Australasian Journal of

Volume 27, Number 1, 2011

ISSN 1449-5554 (online)

\title{
Contents
}

Editorial 27(1)

iii-xii

\section{Outstanding Paper Awards}

An Australian and New Zealand scoping study on the use of 3D

immersive virtual worlds in higher education

Barney Dalgarno, Mark J.W. Lee, Lauren Carlson,

Sue Gregory and Belinda Tynan

Using social network metrics to assess the effectiveness of broad

based admission practices

Shane Dawson, Leah Macfadyen, Lori Lockyer and David Mazzochi-Jones

Key elements of the tutorial support management model

Grace Lynch and Philip Paasuke

Using Slowmation for animated storytelling to represent non-Aboriginal

preservice teachers' awareness of "relatedness to country"

Anthony McKnight, Garry Hoban and Wendy Nielsen

Publishing and perishing: The critical importance of educational

design research

Thomas C. Reeves, Susan McKenney and Jan Herrington

\section{Tertiary sector}

Using video annotation to reflect on and evaluate physical education

pre-service teaching practice

Meg Colasante

From socialisation to internalisation: Cultivating technological

pedagogical content knowledge through problem-based learning

Meng Yew Tee and Shuh Shing Lee

\section{Schools sector}

Information skills and critical literacy: Where are our digikids at with online searching and are their teachers helping?

Judine Ladbrook and Elizabeth Probert

The intersections of curriculum development: Music, ICT and

Australian music education

Jane Southcott and Renée Crawford

Why don't all maths teachers use dynamic geometry software in

their classrooms?

Gerrit Stols and Jeanne Kriek

Integrating online learning in NSW secondary schools: Three schools'

perspectives of ICT adoption

Edwina Neyland 
The Australasian Journal of Educational Technology (AJET) is a refereed research journal published 6 times per year by the Australasian Society for Computers in Learning in Tertiary Education (ascilite). AJET retired its printed version (ISSN 1449-3098) at the end of Volume 23, 2007, and from Volume 24, 2008, the journal is open access, online only (ISSN 1449-5554), and does not have paid subscriptions.

(C) 2010 Authors retain copyright in their individual articles, whilst copyright in AJET as a compilation is retained by the publisher. Except for authors reproducing their own articles, no part of this journal may be reprinted or reproduced without permission. For further details, and for details on submission of manuscripts and open access to all issues of AJET published since the journal's foundation in 1985, please see http:/ / www.ascilite.org.au/ajet/

For editorial inquiries, contact the Editor, Associate Professor Catherine McLoughlin, School of Education (ACT), Australian Catholic University, PO Box 256, Dickson ACT 2602, Australia. Email: Catherine.McLoughlin@acu.edu.au, Tel: +61262091100 Fax +61262091185.

For review process, production, website and business matters, contact the Production Editor, Dr Roger Atkinson, 5/ 202 Coode Street, Como WA 6152, Australia. Email: rjatkinson@bigpond.com, Tel: +61 89367 1133. Desktop publishing (PDF versions) and HTML by Roger Atkinson.

AJET is managed by a Committee comprising ASCILITE Executive nominees, the convenors or nominees from previous ascilite Conferences, and AJET's previous editors and current senior editorial staff. The 2010 Management Committee members are:

Professor Mike Keppell, Charles Sturt University, ASCILITE President

Dr Philippa Gerbic, Auckland University of Technology, ASCILITE Executive

Professor Geoffrey Crisp, University of Adelaide, ASCILITE 2003 Convenor

Dr Rob Phillips, Murdoch University, ASCILITE 2004 Convenor

Professor Peter Goodyear, University of Sydney, ASCILITE 2006 Convenor

Dr Dale Holt, Deakin University, ASCILITE 2008 Convenor

Professor Ron Oliver, Edith Cowan University, AJET Editor 1997-2001

Assoc Prof Catherine McLoughlin (Editor), Australian Catholic University

Dr Roger Atkinson (Production Editor)

AJET's Editorial Board (see http://www.ascilite.org.au/ajet/about/editorialboard.html) reflects the journal's commitment to academic excellence in educational technology and related areas of research and professional practice, our vision of an international journal with an Australasian regional emphasis, and our origins as a professional and learned society publication. 


\section{Editorial 27(1)}

\section{Five Outstanding Paper Awards made at ascilite Sydney 2010}

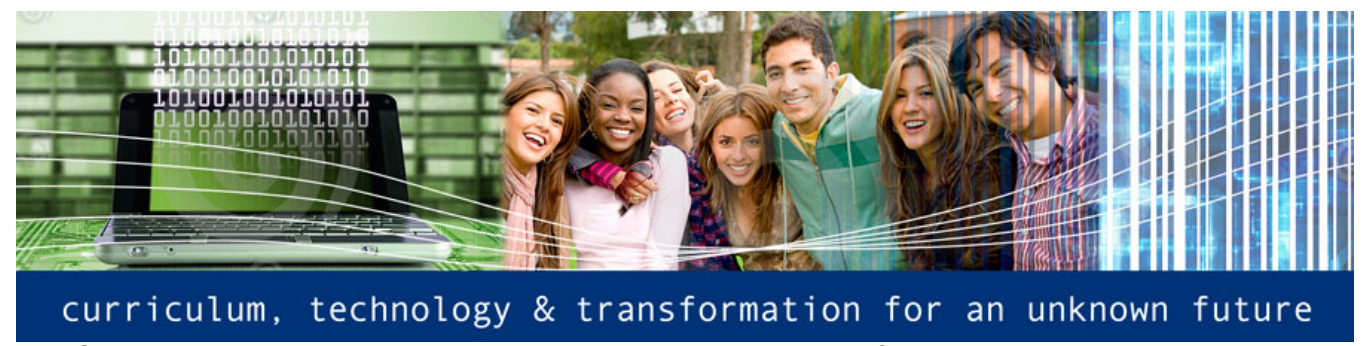

Sydney, 5-8 Dec 2010. Proceedings at http://www.ascilite.org.au/conferences/sydney10/proceedings.htm

The five Outstanding Paper Awards announced at ascilite Sydney 2010 constitute a very worthy continuation of this series, which was initiated in 2000 by $\mathrm{Dr}$ Ron Oliver [1] after Responding to diversity: ASCILITE Brisbane 1999 [2]. The 2010 Awards noted below are in alphabetical order by first author for AJET 27(1) presentation.

The Award winning paper by Barney Dalgarno, Mark J. W. Lee, Lauren Carlson (Charles Sturt University), Sue Gregory and Belinda Tynan (Univerity of New England) is titled An Australian and New Zealand scoping study on the use of 3D immersive virtual worlds in higher education. It has an immediate follow up in AJET, with the release in this issue of the call for articles for an AJET Special Issue 2012 (see below), titled Virtual worlds in tertiary education: An Australasian perspective, edited by Mark J. W. Lee, Barney Dalgarno and Helen Farley [3].

Using social network metrics to assess the effectiveness of broad based admission practices reports research by Shane Dawson, Leah Macfadyen (University of British Columbia), Lori Lockyer and David Mazzochi-Jones (University of Wollongong). Their paper investigates the admissions criteria that best predict student engagement in a social learning environment and thus the related attributes such as communication, creativity, and leadership.

Grace Lynch and Philip Paasuke from Open Universities Australia wrote Key elements of the tutorial support management model, a well-planned approach that has provided benefits in terms of improved student retention, performance, and satisfaction in addition to increased return and re-enrolment rates.

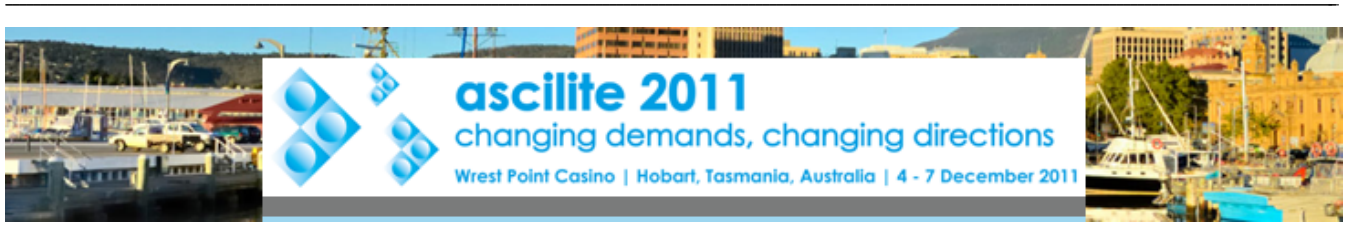

Hobart, 4-7 December 2011. http://www.ascilite.org.au/conferences/hobart11/ 


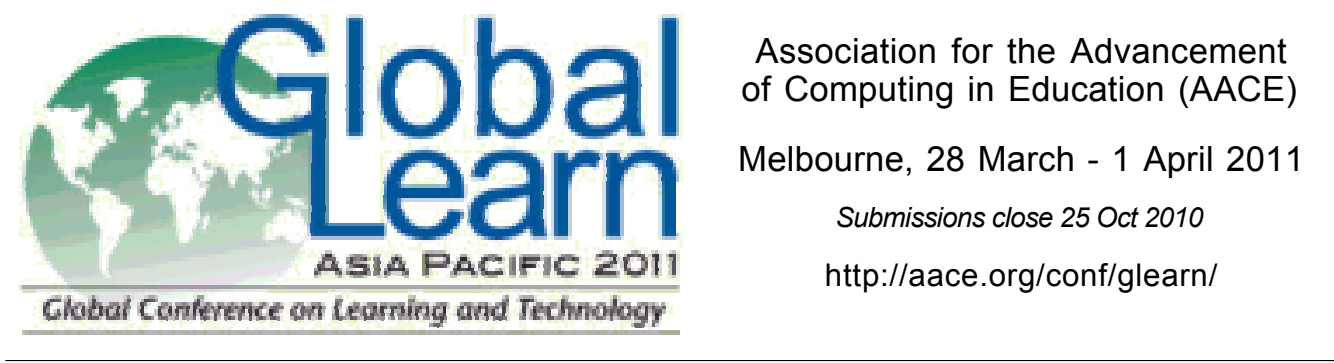

The paper Using Slowmation for animated storytelling to represent non-Aboriginal preservice teachers' awareness of "relatedness to country" by Anthony McKnight, Garry Hoban and Wendy Nielsen (University of Wollongong) presents a uniquely purposeful application of a simple technique for animated story telling. It illustrates a creative way to develop students' awareness of cultural diversity, with particular reference to Aboriginal ways of knowing.

Publishing and perishing: The critical importance of educational design research was authored by Thomas C. Reeves (The University of Georgia), Susan McKenney (University of Twente) and Jan Herrington (Murdoch University). They advance a compelling discussion about the "disconnect between the educational research papers published in professional journals or presented at academic conferences and any form of beneficial impact on the students, teachers, and other stakeholders in educational systems."

We congratulate the authors of the five Outstanding Paper Awards, and express the hope that aspiring authors will find it rewarding to study the examples and the standard setting that these Awards provide.

\section{Announcing AJET's third Special Issue}

AJET's Volume 28 Special Issue will be Virtual worlds in tertiary education: An Australasian perspective, edited by Mark J. W. Lee (Charles Sturt University and University of New England), Dr Barney Dalgarno (Charles Sturt University) and Dr Helen Farley (University of Southern Queensland) for the DEHub Virtual Worlds Working Group. Readers are invited to view the Call for articles [3], initiated at the same time as publication of AJET 27(1).

With AJET's second Special Issue [4] now well advanced after a very strong response from prospective authors, and with several more Special Issue negotiations currently in progress, we anticipate that AJET will develop quickly towards two Special Issues per year, with some instances of three per year.

\begin{tabular}{lc}
\hline CAUDIT CAUL ACODE \\
$\begin{array}{l}\text { CCA-EDUCAUSE } \\
\text { AUSTRALASIA } 2011\end{array}$ \\
THE GAME HAS CHANGED & $\begin{array}{c}\text { The game has changed } \\
\text { Sydney, 3-6 April 2011 } \\
\text { http://ccaeducause.cauditedu.au/ } \\
\text { index.php/educause/ccae2011 }\end{array}$ \\
\hline
\end{tabular}




\section{LAN/S Learning Design for a Ganging Worlo $20 / 1$ Asia Pacific LAMS and Learning Design Conference}

Nanyang Technological University, Singapore, 6-7 June 2011. http://lams2011.lamsfoundation.org/

\section{Revisiting the 'growth spurt' in educational technology journals}

Figure 1 illustrates the large increases in 'annual output' that have occurred during the past decade, for six leading international journals in educational technology. An earlier version of Figure 1, for 2001-2007, suggested a 'growth spurt' [5] and three years later it is clearly a 'sustained growth spurt'. What is less clear, though now very important indeed, is the question of whether large increases in 'annual output' have been obtained by similarly large increases in acceptance rates, and if that has

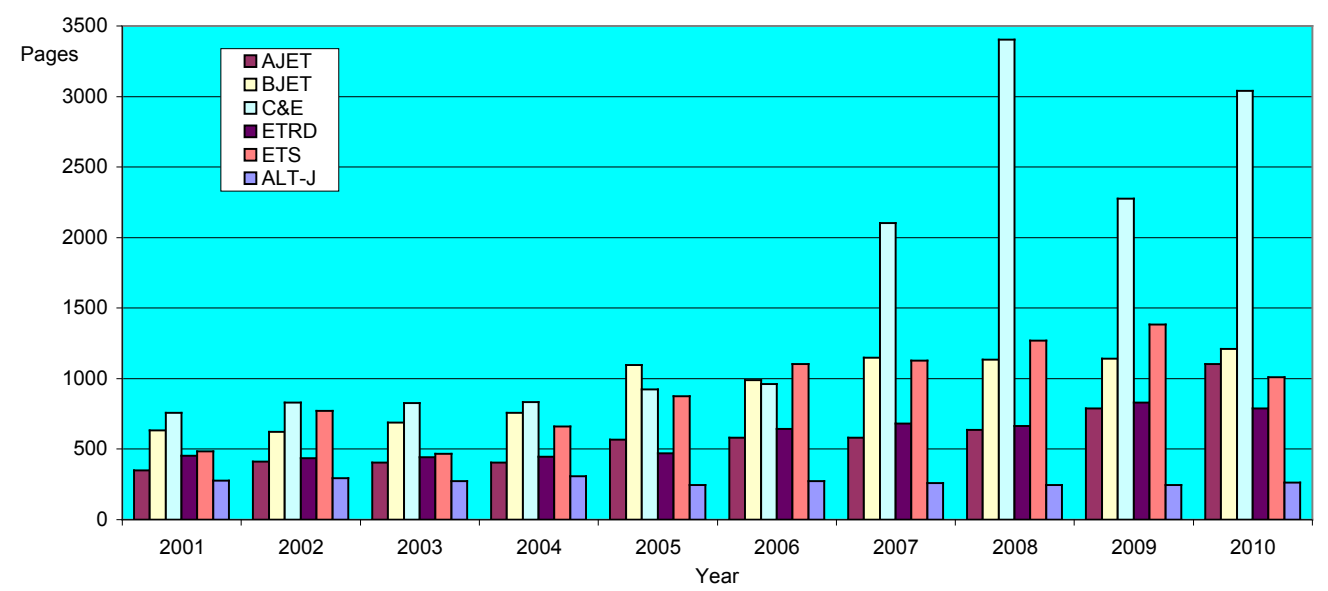

Figure 1: Number of pages per year for six educational technology journals. Page counts are from each journal's website, excluding Roman numbered pages but including book reviews and other non-Roman page numbered content.

\begin{tabular}{|l|l|}
\hline \multicolumn{1}{|c|}{ Journal } & \multicolumn{1}{c|}{ URL } \\
\hline $\begin{array}{l}\text { Australasian Journal of } \\
\text { Educational Technology }\end{array}$ & $\begin{array}{l}\text { http://www.ascilite.org.au/ajet/ } \\
\text { (Tier B) }\end{array}$ \\
\hline $\begin{array}{l}\text { British Journal of } \\
\text { Educational Technology }\end{array}$ & $\begin{array}{l}\text { http:/ / www.wiley.com/bw/journal.asp?ref=0007-1013 } \\
\text { (Tier A) }\end{array}$ \\
\hline Computers \& Education & http:/ / www.elsevier.com/locate/issn/03601315 (Tier A) \\
\hline $\begin{array}{l}\text { Educational Technology, } \\
\text { Research \& Development }\end{array}$ & $\begin{array}{l}\text { http:/ / www.springer.com/east/home/education/learning+\%26+instructio } \\
\text { n?SGWID=5-40666-70-50612191-detailsPage=journal / description (Tier A) }\end{array}$ \\
\hline $\begin{array}{l}\text { Educational Technology } \\
\text { \& Society }\end{array}$ & $\begin{array}{l}\text { http: / / www.ifets.info/ others / } \\
\text { (Tier B) }\end{array}$ \\
\hline $\begin{array}{l}\text { ALT-J: Research in } \\
\text { Learning Technology }\end{array}$ & $\begin{array}{l}\text { http:/ / www.tandf.co.uk/journals/titles/09687769.asp } \\
\text { (new name 2011: Research in Learning Technology) (Tier A) }\end{array}$ \\
\hline
\end{tabular}

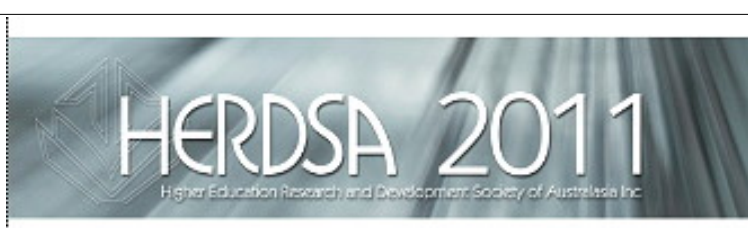

HERDSA 2011

Higher education on the edge

Gold Coast, Queensland

4-7 July 2011

http://conference.herdsa.org.au/2011/ 


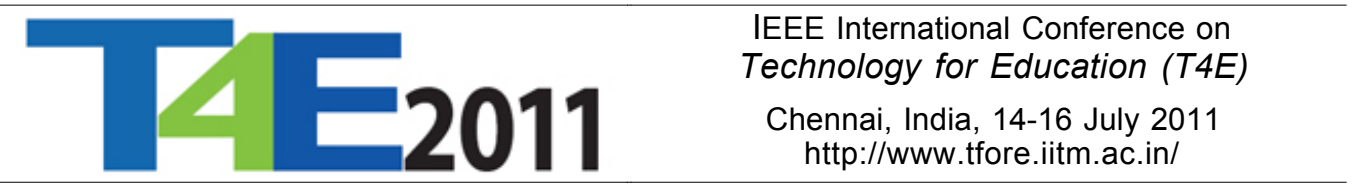

happened, has it led to a decrease in the "Quality of the papers", in particular as perceived by "Tiers for the Australian Ranking of Journals" [6]? Tiers postulates that for a Tier $A^{*}$ journal, "Virtually all papers they publish will be of a very high quality", and for Tier A journals (such as BJET, C\&E, ETR\&D and ALT-J in Figure 1), "The majority of papers in a Tier A journal will be of very high quality" [6]. Can a journal such as C\&E (for example) double or treble its annual output within about five years and sustain the criterion "majority of papers ... very high quality"?

As an aside, we note that the Tiers attitude towards B ranked journals (such as AJET and ET\&S in Figure 1) is almost dismissive: "Generally, in a Tier B journal, one would expect only a few papers of very high quality" [6]. We hope that the recipients of the ascilite Sydney 2010 Outstanding Paper Awards honoured in this issue of AJET are not unduly piqued by the Tiers characterisation of AJET!

The question of relationships between "Quality of the papers" and a journal's number of articles published per year may warrant some extensive research, along with a probing into the other features of quality that are nominated as underpinning Tiers, namely acceptance rates and the composition of editorial boards [6].

\section{ALT's journal to become fully open access}

The Association for Learning Technology's journal, Research in Learning Technology (previously named ALT-J: Research in Learning Technology) will change publisher and become fully open access from January 2012 [7]. After some years of publication by the Taylor \& Francis Group [8], the new arrangement for ALT's journal will feature full open access via Co-Action Publishing [9]. As announced by ALT's Chief Executive, Seb Schmoller:

Following last year's reprocurement process, and with the support of ALT's Research Committee and of the journal's Editorial Board, I am happy to report that from January 2012 our journal will be fully Open Access, produced in partnership with the Swedish publisher Co-Action Publishing. We are about to complete negotiations on the new publishing agreement with Co-Action, and once finalised the process of transfer of the journal from the current publisher to Co-Action will then begin, taking final effect at the end of 2011.

This change represents a major development for ALT. One effect will be that the contents of Research in Learning Technology will be much more accessible to people world-wide than at present. Another will be much better integration between the journal and the ALT conference. A third is likely to be a modest reduction in the annual costs of organisational membership of ALT, from February 2012. [7]

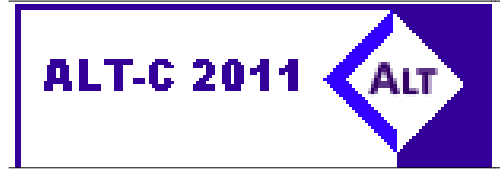

Association for Learning Technology: ALT-C 2011 Thriving in a colder and more challenging climate

University of Leeds, UK, 6-8 September 2011 http://www.alt.ac.uk/altc2011/ 


\title{
Review of the ERA 2010 Ranked Outlet Lists
}

The Australian Research Council's process for its Review of the ERA 2010 Ranked Outlet Lists is now in progress [10]. The ascilite Executive's recent advice to members about the Review included the following concerning AJET [11].

\begin{abstract}
Phase 1: Public Consultation
The ascilite executive and AJET Management Committee strongly encourage ascilite members and their colleagues interested in the field of learning technologies to participate during the public consultation period. As you may know, our field did not fare well in ERA 2010. For more details, see AJET Editorial 26(1), "Journal rankings: AJET demoted", http: / / www.ascilite.org.au/ajet/ajet26/ editorial26-1.html, for a summary of tier changes in learning technology journals 2008-2010, and AJET Editorial 26(5), Table 2, http:/ / www.ascilite.org.au/ajet/ajet26/ editorial26-5.html, for an AJET ranking according to Impact Factor. We urge you to consider the learning technology journals carefully.
\end{abstract}

Many ascilite members have expressed concern about the demotion of AJET from an 'A' level to a ' $\mathrm{B}$ ' level journal. If, in your own scholarly opinion, you consider that AJET should be promoted then you may find the following of interest:

- In Thomson Reuters Journal Citation Reports for 2009 AJET came in at No. 29 out of 139 Education journals, with an Impact Factor of 1.278 (http:/ / www.ascilite.org.au/ajet/ajet26/ editorial26-5.html).

- AJET has a rigorous acceptance regime and is one of very few journals publishing detailed statistics on review outcomes. [12]

- AJET's growth has now matched or exceeded the growth rates of most learning technology journals with 7 issues / year, inc. at least 1 special issue. AJET submissions/year increased 46\% from 2008 to 2009, 26\% from 2009 to 2010, whilst acceptance remained stable in the range 29-33\% during 2005-2009.

- AJET's Editorial Board has a good mix of eminent researchers and rising new talent, a modern gender balance, and outreach towards Australasian region countries (http://www.ascilite.org.au/ajet/about/editorial-board.html).

Phase 2: Review by contracted peak bodies

For the second phase of ERA2012, ascilite is currently working collaboratively with key organisations like AARE, HERDSA and AVETRA [13] for a coordinated/ consortium 'peak body' approach for publications under the FoR13 field. As a premier professional society for learning technologies in education, ascilite will seek to provide unbiased expertise on the quality of all journals in the learning technology field. ascilite also plans to consult with ACODE, ACCE and ODLAA [14]. As best we can ascertain from our current knowledge of the ERA 2010 and 2012 processes, we believe this is the most positive way to contribute to and influence the ERA 2012 outcomes for our field and our members. For some insights into what we have to do, members are invited to view the documents 'ROCI_PeakBodies_20110219.csv' (current list of 'peak bodies' [15]) and 'ERA_2012_ranked_outlets.pdf' (496 kB, 65 pages, see especially para. 1.1.7, page 4) [16].

Most unfortunately, or possibly quite deliberately, the ARC's deadline for tenders to become a 'contracted peak body' was set at an early date, '4:00pm (AEDT), 15 March 2011' (fax or email submission denied!). The file 'ERA_2012_ranked_outlets.pdf' [16]

5th Asia Pacific Conference
on Educational Integrity
The University of Western Australia
Perth, 26-28 September 2011
http://www.catl.uwa.edu.au/5apcei


is a long and complex document. Many observers may form the view that it is designed to deter tenderers, not to encourage them. In particular, the document seems to give no explicit scope for specifying the Fields of Research ('FoR') for which a tenderer is best suited to be involved. Does the ARC have a predetermined view about the numbers and kinds of organisation that it prefers to have commissioned as 'service provider(s)'? Some clauses seem to imply an acceptance of specialised tenders (i.e. specifying an FoR), for example, note the key phrase or for titles... :

ix. Tendered fees

1.2.20 Tendered fees are to be provided for the finalisation of the entire ERA ranked outlet lists or for titles belonging to disciplines (i.e. FoR codes) within the lists. [16]

However, elsewhere in the document, in particular in the section 'Tender Response Form', there seems to be no provision for a tenderer to specify the FoRs being tendered for (e.g. FoR 13 Education, or 1301 Education Systems, or 1302 Curriculum and Pedagogy, or 1303 Specialist Studies in Education, or 1399 Other Education; or some combination of FoRs) [17].

The ARC was unable to give an estimate of the amount of work to be done by the 'contracted peak bodies'. However, by reference to its development of the ERA 2010 ranked outlet list, the ARC indicates an expectation that Phase 1: Public Consultation will be quite large:

- Public consultation 1 - feedback was sought from the sector regarding the draft journal rankings initially developed by the four Learned Academies. Approximately 100,000 pieces of feedback from 109 organisations were received in this phase of consultation.

- Public consultation 2 - the ARC released the draft list without ranks and FoR codes to allow the sector to identify eligible missing journals. The ARC received over 4,000 requests for new journals to be added.

- Direct Consultation - the ARC approached over 700 expert reviewers and peak bodies to assist with the finalisation of the ERA 2010 ranked journal list. [16, clause. 1.1.7]

Many observers may form the view that the ARC is fearful of being "swamped" by a very large volume of feedback, and that it has devoted its efforts to coping with volume, rather than trying to understand and learn from feedback. Providing feedback is actually quite difficult, being tightly structured in Phase 1: Public Consultation by 'ROCI' (Research Outlet Consultation Interface) [18]. We urge readers to register with ' $\mathrm{ROCI}$ ', not only to provide some feedback, but also to explore it as a case study in interface design. To mention just two details of the design, ' $\mathrm{ROCI}$ ' does not allow you to read comments by others, and does not allow you to revisit and edit your own comments. It does contrast quite sharply with numerous well-designed interfaces that AJET readers may be familiar with, for example MyReview [19] (used by ascilite, HERDSA and DEHub-ODLAA for peer review of conference submissions),

Fifth Joint Conference of APACALL and PacCALL
Do La local Salle University
Manila, Philippines
$27-29$ October 2011
http://glocall.org/


Getup's Campaign Ideas Forum [20] (used during February 2011 for 'Reversing the govt's decision to abolish the Australian Learning \& Teaching Council', a campaign initiated by Peter Goodyear [21]), and of course the 'comment' interfaces used by media organisations such as the $\mathrm{ABC}$ [22]. To mention another example of tight structuring of feedback that readers may wish to inspect, the ARC released recently ERA Consultation - March 2011 - form for completion [23].

Of course, as may be usual in these matters, it is the unstructured, or unsolicited, or 'un-orchestrated' feedback that may be the most significant, and certainly the most accessible, as it appears in conventional publications. Some professional societies are openly critical, for example, the AARE could be seen as projecting a view that the Australian Government will fail to follow up on certain insights already available from ERA 2010 [24]. Will the Government give less to disciplines such as Engineering in order to increase Education to a fairer share?

ERA hides more than it reveals about Education research.

ERA confirms two things for Education. Investment in research produces returns and ERA is not a level playing field.

Education (FoR13) produced 5\% of national research outputs but only received $1 \%$ of the HERDC Category 1 research income. This means Education ranked 22/25 in terms of government funding of research per full-time equivalent (FTE) academics compared with Engineering $(4 / 25)$, Economics $(12 / 25)$, History and Archaeology $(17 / 25)$ and Philosophy and Religious Studies (19/25). [24]

Some media outlets have taken a critical interest in journal ranking, for example, the Australian's recent articles 'Why lists are a flawed approach to assessing excellence' [25] and 'Journal rankings don't reflect performance') [26], and Pontille and Torny (2010) have provided a very timely research article, 'The controversial policies of journal ratings: Evaluating social sciences and humanities' [27].

Clearly, journal rankings will be a hot topic for some considerable time. Already we seem to have at least three main directions emerging. Firstly, there is the immediate matter of trying to secure a higher or fairer or more logical ranking for one's own journal. Secondly, the process adopted by the Review of the ERA 2010 Ranked Outlet Lists is likely to come under greater scrutiny. After all, the ARC should be absolutely impeccable and beyond reproach in the research methodology that it uses to underpin its policies and practices. Thirdly, investigation of the utility, appropriateness and validity of journal rankings and other aspects of the ERA process is likely to widen. However, to date there seems to be no indication about a fourth main direction that ought to emerge: the ARC reviewing its adherence to the concept that journal rankings satisfy utility, appropriateness and validity criteria. The ARC may intend to ease the pressure a little by softening its stance on the rigidly normative nature of

\section{0th Biennial Conference}

Forging New Directions in Academic Language and Learning

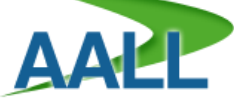

Association for Academic Language and Learning

Adelaide, 24-25 November 2011. http://www.adelaide.edu.au/clpd/aall2011/ 
Tiers (5\% A* $15 \% \mathrm{~A}, 30 \% \mathrm{~B}, 50 \% \mathrm{C})$, as a recent article in The Australian [26] may suggest. In commenting upon some data tables concerning high-performing disciplines, ARC CEO Professor Margaret Sheil is reported to have said, "It shows that the proportion of $\mathrm{A}^{*}$ and $\mathrm{A}$ journals did not correlate directly with the performance of different disciplines" [26]. We note that references to $5 \% A^{*} \ldots$ seem to have disappeared from the ERA website, or have become deeply buried. Could we be on the verge of something less severely normative, e.g. $10 \% \mathrm{~A}^{*}, 20 \% \mathrm{~A}, 35 \% \mathrm{~B}, 35 \% \mathrm{C}$ ?

\section{AJET Editorial Board: Annual feedback sought}

On 21 Dec 2010 we emailed the following invitation to AJET's Editorial Board [28].

Greetings all,

Our announcement of AJET's new Editorial Board, dated May 2009 in AJET Editorial 25(2), included the sentences:

"We envision the Board's primary role to be acting as an independent monitor of AJET's editorial standards, with particular reference to comparing AJET with similar international journals. The principal method for providing feedback to AJET's editorial staff and the Management Committee will be responding to an annual open ended questionnaire, although other avenues may be used."

This is the first of the promised annual, open ended questionnaires! We are not seeking lengthy, time consuming responses, brief "takes" or "impressions" will be very appropriate, concentrating on the principal question, "How do you perceive AJET's standards and standing, compared with similar international journals?"

We would like also to draw some attention to several more specific questions. Firstly, dating back to its inception in 1985, AJET has been a "generalist" educational technology journal drawing articles from both higher and further education and the schools sectors. Does this seem to you to be appropriate? Or will AJET's fortunes be better progressed as a more specialised journal, for example tertiary education only?

Secondly, AJET fared well in the first version of the Australian Research Council's Tiers ranking of journals (with an "A" rank), but was demoted in the second version (to a "B" rank), though we are hopeful that in the third version to be developed during 2011 AJET will regain an "A" Tier ranking. What strategies can you suggest as especially productive for AJET to pursue towards the goal of becoming a "top 5" international research journal in educational technology, and also a "Tier A" in Australia?

Thirdly, how should we best develop "AJET's aspirations to be a front ranked international journal with an Australasian character", as indicated in Editorial 23(4)? We have an increasing representation from our principal 'Australasian' supporters in Singapore, Malaysia, Hong Kong and more recently Taiwan. Will this serve as new 'bases' for linking into the broader continental Asian, South Pacific and Indian Ocean rim countries?

As we want this email and the tasks it contains to be reasonably brief, and economical with everyone's time, we suggest that for further delineation of the contexts for these key questions, you could scan recent Editorials, including:

* AJET Editorial 26(7). AJET report to ascilite AGM 2010. http:/ / www.ascilite.org.au/ajet/ajet26/editorial26-7.html (see AJET report to ascilite AGM 2010, includes a statement about AJET's scope and its role as a community service flagship) (note that AJET 26(7) is in 'production mode', target was 'before Christmas, is now 'before New Years' Eve')

* AJET Editorial 26(6). A Letter to the Editor: Defending the ERA initiative. http: / / www.ascilite.org.au/ajet/ ajet26/ editorial26-6.html 
* AJET Editorial 26(5). http:/ / www.ascilite.org.au/ajet/ajet26/ editorial26-5.html (see Idle Moment 40: Impact Factor revisited, includes advice about AJET's first Impact Factor, 1.278; see also 'AJET review process outcomes: 2009 data')

* AJET Editorial 26(1). AJET demoted. http: / / www.ascilite.org.au/ajet/ ajet26/ editorial26-1.html

* AJET Editorial 23(4). Internationalisation revisited; Growth rates for some leading journals. http: / / www.ascilite.org.au/ajet/ajet23/ editorial23-4.html

As to replies, feel free to reply to the Editors only, or to the whole Board, as you wish. If replying to the Editors only, please indicate the extent to which you prefer that your feedback to be confidential to the editors, or collated anonymously for all to see, or whatever (we do adhere to an ethic about publishing a person's private writings only by mutual agreement). Also, please do not feel constrained by the "scoping" questions given here, feel free to raise any relevant issues.

Finally, our best wishes for end of year relaxing, reflecting, festivities / Merry Christmas and Happy NewYear/ Seasons greetings time! Do please fit your response to this email into that timeframe, replies by mid-January would be much appreciated, in plain text or as attached file if you prefer. It may be best to be quick, brief and incisive, in contrast to the antonymic.

Catherine McLoughlin and Roger Atkinson

AJET Editor and Production Editor, 21 Dec 2010

The AJET Board's duty statement and the background to its inauguration are given in Editorial 25(2) [29]. Of the current 30 members, 15 have replied to date. Regretably, absorbing this feedback is now subject to delays imposed by the more urgent current tasks, namely attending to the Review of the ERA 2010 Ranked Outlet Lists, and decreasing the backlog in AJET's review process (it is necessary to produce review outcomes advice emails at an average rate of rate of about five per week, to stabilise the numbers in the 'pending' category). To give an initial, brief indication, the principal question, "How do you perceive AJET's standards and standing, compared with similar international journals?" did not generate any specific comment, there being no mentions of AJET's main competitors for Tier A positions (the journals listed in Table 1 in this Editorial), although there were numerous suggestions about how to improve AJET, market it better, and redefine "Australasian". Feedback to date has concentrated on one aspect of the secondary question, "Or will AJET's fortunes be better progressed as a more specialised journal, for example tertiary education only?" Twelve of the fifteen responses to date singled out "tertiary education only" as the most appropriate direction to take. What we will need to do, after outcomes from the current Tiers review are known (thus giving a better indication of what really is important), and prior to AJET Management Committee's consideration, is undertake some further research into how AJET compares with "similar international journals".

Roger Atkinson and Catherine McLoughlin

AJET Production Editor and AJET Editor

\section{Endnotes}

1. AJET Editorial 16(1) (2000). http:/ / www.ascilite.org.au/ajet/ajet16/editorial16-1.html

2. Responding to diversity: Proceedings ASCILITE Brisbane 1999.

http:/ / www.ascilite.org.au/conferences/brisbane99/papers/papers.htm

3. Call for articles: Vol 28 Special Issue: Virtual worlds in tertiary education: An Australasian perspective. http:/ / www.ascilite.org.au/ajet/about/special-issues/virtual-worlds-2012.html 
4. AJET Call for articles: Volume 27 Special Issue: Assessing students' Web 2.0 activities in higher education. http: / / www.ascilite.org.au/ajet/about/special-issues / assess-studentsweb2-2011.html

5. AJET Editorial 23(4), 2007. Idle Moment No. 24: Growth rates for some leading journals. http: / / www.ascilite.org.au/ajet/ ajet23/editorial23-4.html

6. Australian Research Council (ARC) (2009). Tiers for the Australian Ranking of Journals. http: / / www.arc.gov.au/era/tiers_ranking.htm

7. Association for Learning Technology (2011). Newsletter - Issue 22 - Chief Executive's Report. http: / / newsletter.alt.ac.uk/1x02b4s5qza

8. Research in Learning Technology. http://www.tandf.co.uk/journals/titles/09687769.asp

9. Co-Action Publishing. http: / 9www.co-action.net/

10. ARC (2011). Review of the ERA 2010 Ranked Outlet Lists. http: / / www.arc.gov.au/era/era_2012/review_of_era10_ranked_outlet_lists.htm

11. Email from Caroline Steel to ascilite members list, subject 'Learning technologies and ERA2012', 21 Feb 2011 08:51:46 +1030.

12. The most recent tabulation is in AJET Editorial 26(5), AJET review process outcomes: 2009 data. http:/ / www.ascilite.org.au/ajet/ajet26/editorial26-5.html (in 2010 AJET received 235 submissions)

13. AARE http:/ / www.aare.edu.au/; HERDSA http:/ / www.herdsa.org.au/ AVETRA http:/ / avetra.org.au/

14. ACODE http://www.acode.edu.au/; ACCE http:/ / www.acce.edu.au/ ODLAA http:// www.odlaa.org/

15. This list is updated from time to time, obtain the current version from https: / / roci.arc.gov.au/Home/PeakBodyList

16. ARC (2011). ATM 66 - Provision of review and recommendations for the ERA 2012 ranked outlets. Obtain via http: / / www.arc.gov.au/about_arc/tenders.htm ('ATM' is 'Approach to market', i.e. a call for tenders)

17. For efficient access to FoR data, we use Lamp, J. (2010). ERA Current Rankings Access. http:/ / lamp.infosys.deakin.edu.au/era/

18. ARC (2011). ROCI - Research Outlet Consultation Interface. https: / roci.arc.gov.au/

19. MyReview. http: / / myreview.lri.fr/

20. Getup. Campaign Ideas Forum. http:/ / suggest.getup.org.au/forums / 60819-campaign-ideas

21. Getup (2011). Reversing the govt's decision to abolish the Australian Learning \& Teaching Council. http: / / suggest.getup.org.au / forums / 60819-campaign-ideas / suggestions / 1416367reversing-the-govt-s-decision-to-abolish-the-austr?lang=en

22. For example, the ABC's 'The Drum', http:/ / www.abc.net.au/thedrum/

23. ARC (2011). ERA Consultation - March 2011 - form for completion. http:/ / www.arc.gov.au/era/era_2012/era_consultation_march11.htm

24. AARE (2011). ERA hides more than it reveals about Education research. [viewed 13 Mar 2011] http:/ / www.aare.edu.au /

25. Tourish, D. (2011). Why lists are a flawed approach to assessing excellence. The Australian, 2 March. http: / / www.theaustralian.com.au/higher-education/opinion-analysis/ why-listsare-a-flawed-approach-to-assessing-excellence/ story-e6frgcko-1226014065961

26. Rowbotham, J. (2011). Journal rankings don't reflect performance. The Australian, 9 March. http: / / www.theaustralian.com.au/higher-education/journal-rankings-dont-reflectperformance/story-e6frgcjx-1226017977717

27. Pontille, D. \& Torny, D. (2010). The controversial policies of journal ratings: Evaluating social sciences and humanities. Research Evaluation, 19(5), 347-360. http: // halshs.archivesouvertes.fr / halshs-00568746/fr / (also at http:/ / www.ingentaconnect.com/ content / beech / rev/2010/00000019/00000005/art00004)

28. AJET Editorial Board. http:/ / www.ascilite.org.au/ajet/about/editorial-board.html

29. AJET Editorial 25(2), 2009. Announcing AJET's new Editorial Board. http:/ / www.ascilite.org.au / ajet/ajet25/editorial25-2.html

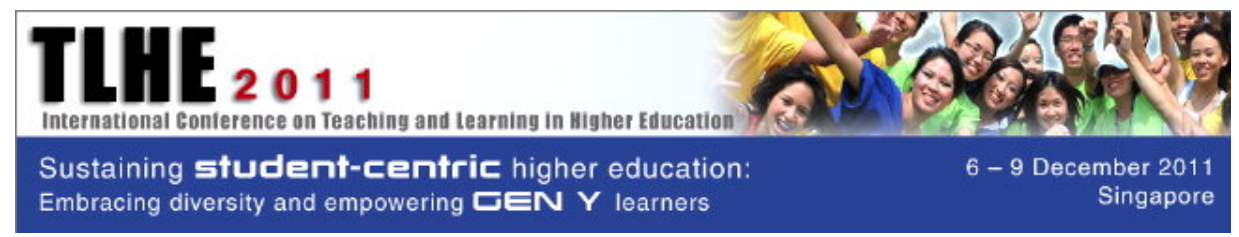

Singapore, 6-9 December 2011. http://www.cdtl.nus.edu.sg/the/ 